\section{Damage to Cut Roses from Fluoride in Keeping Solutions Varies with Cultivar}

\author{
Virginia I. Lohr and Caroline H. Pearson-Mires \\ Department of Horticulture and Landscape Architecture, Washington \\ State University, Pullman, WA 99164-6414
}

Additional index words. cut flowers, fluoride injury, postharvest quality, Rosa hybrids

Abstract. Cut flowers of eight cultivars of Rosa hybrida L. were held in preservative solutions containing up to $4 \mathrm{mg} \mathrm{F}$-/liter. Leaf diffusive resistance was increased by holding flowers in F- solutions. In most cultivars, fresh weight gain was decreased, the degree of flower opening was affected, and visual symptoms of injury were noted in the presence of. $\mathrm{F}$ - in the holding solution. Damage at $2 \mathrm{mg} \mathrm{F}$-/liter was almost as severe as at $4 \mathrm{mg} / \mathrm{liter}$. Number of days to petal abscission or bent-neck was shortened by F- for 'Samantha' and 'Bridal Pink'.

Fluoride, whether in the atmosphere or in solution, is toxic to many plants and animals (Miller et al., 1983). Fluoride causes injury to some cut flowers at rates as low as 1 $\mathrm{mg} \cdot$ liter $^{-1}$; additional species and cultivars are damaged by higher rates (Lohr and Pearson-Mires, 1989; Spierings, 1969; Tjia et al., 1987; Waters, 1968). Flowers often are held in fluoridated water, because many municipalities add F- to their water to reduce tooth decay in humans. Current federal regulations allow up to $4 \mathrm{mg}$ F-/liter to occur in. drinking water (U.S. Government, 1986).

Fluoride injury has been reported in 'Tropicana'. (Waters, 1968) and 'Samantha' (Lohr and Pearson-Mires, 1989) roses, but the extent of injury and the symptoms of injury in other rose cultivars are not known. Waters (1968) reported that injury symptoms were easier to evaluate on 'Tropicana', an orange cultivar, than on 'Red American Beauty', a dark red cultivar. The purpose of our research was to examine the susceptibility of additional cultivars of cut roses to damage from $\mathrm{F}$ - at levels that can occur in drinking water. 'Samantha' was included in this study as a comparison cultivar.

Cut roses were obtained from a wholesale supplier on two dates (Trials 1 and 2). Eight cultivars were examined. In Trial 1, we tested 'Bridal Pink', 'Kyria', 'Prive', 'Samantha', and 'Sonia'. When received (Day 0), flower stems were cut under water to $24 \mathrm{~cm}$ and leaves were removed from the lower 16 to $18 \mathrm{~cm}$ of the stem. Flowers were placed in deionized water with $200 \mathrm{mg} 8$ hydroxyquinoline citrate/liter and $2 \%$ su-

\footnotetext{
Received for publication 31 Mar. 1989. H/LA paper no. 88-21. Project no. 0695, College of Agriculture and Home Economics Research Center, Pullman, WA 99164. Appreciation is expressed to Don Jacobson, Jacobson Greenhouses, Spokane, Wash., for donating the flowers used in this experiment. The cost of publishing this paper was defrayed in part by the payment of page charges. Under postal regulations, this paper therefore must be hereby marked advertisement solely to indicate this fact.
}

crose (control solution). Leaf diffusive resistance was measured after at least $1 \mathrm{hr}$ under a light intensity of $145 \mu \mathrm{mol} \cdot \mathrm{s}^{-1} \cdot \mathrm{m}^{-2}$ using a LI-COR steady state porometer (LI-COR, Lincoln, Neb.). Initial fresh weight, degree of flower opening, and visual observations were recorded. Stems were then placed randomly in individual polyethylene bottles containing the control solution with 0 or 4 $\mathrm{mg} \mathrm{F}$ - (as NaF) per liter. Solutions with preservatives were used because roses are commonly held in this manner and because preliminary studies using these solutions, as well as water alone and water with $\mathrm{F}$-, indicated that there was no synergism between the F- and preservative.

Flowers were held under cool-white fluorescent lamps $\left(56 \mu \mathrm{mol} . \mathrm{s}-1 . \mathrm{m}^{-}{ }^{\mathrm{z}}\right)$ for $9 \mathrm{hr}$ daily at 24C. On Days 1 and 2, leaf diffusive resistance was measured as described for Day $\mathrm{O}$. Fresh weight, visual observations, and degree of flower opening were recorded daily. Degree of flower opening was recorded on a scale from 1 through 7 , with $1=$ bud open slightly at the apex, $3=$ petals forming a loose cylindrical roll, $5=$ up to $50 \%$ of the outer petals reflexed at about right angles to the stem, and $7=$ more than $50 \%$ of the outer petals reflexed and stamens visible. Flower longevity, defined as the number of days from the start of the experiment until the flower exhibited bent-neck or petal abscission, also was determined.

Flowers for Trial 2 were treated as described for Trial 1, except diffusive resistance was not measured and flowers were placed in the control solution with $\mathrm{O}, 2$, or $4 \mathrm{mg}$ F-/liter. Cultivars tested in Trial 2 were 'Bridal White', 'Candia', 'Golden Wave', and 'Samantha'.

Leaf diffusive resistance increased over time and was higher in flowers in solutions containing $4 \mathrm{mg} \mathrm{F}$-/liter than in flowers in control solutions. There was no significant interaction between F- treatment and cultivar, thus indicating that-all cultivars responded similarly. The results for 'Prive' (Fig. 1) are representative of the five cultivars measured. Increases in diffusive resistance were seen within 1 day of placing cut roses in solutions with F-. Atmospheric F- has been associated with stomatal closure in soybeans, and reduced transpiration has been noted after only $4 \mathrm{hr}$ of exposure (Poovaiah and Wiebe, 1973).

'Bridal Pink', 'Candia', 'Prive', and 'Samantha' roses in solutions containing $4 \mathrm{mg}$ F-/liter gained less weight than those in control solutions (Table 1). These cultivars in F- solutions also lost weight sooner than when in solutions without F- (Fig. 2; results for 'Samantha' are representative of these cultivars). 'Candia' and 'Samantha' also were tested in $2 \mathrm{mg}$ F-/liter and responded similarly to those in $4 \mathrm{mg} \cdot$ liter $^{-1}$ (Table 1). Other researchers have reported wilting of various crop plants in the presence of F- (Leone et al., 1948). Reduced water uptake could account for these results. Fresh weight changes in 'Bridal White', 'Golden Wave', 'Kyria', and 'Sonia' were not significantly altered by F-.

The opening of 'Bridal Pink', 'Prive', 'Samantha', and 'Sonia' roses placed in solutions containing F- was different than that for roses in the control solution (Table 1).

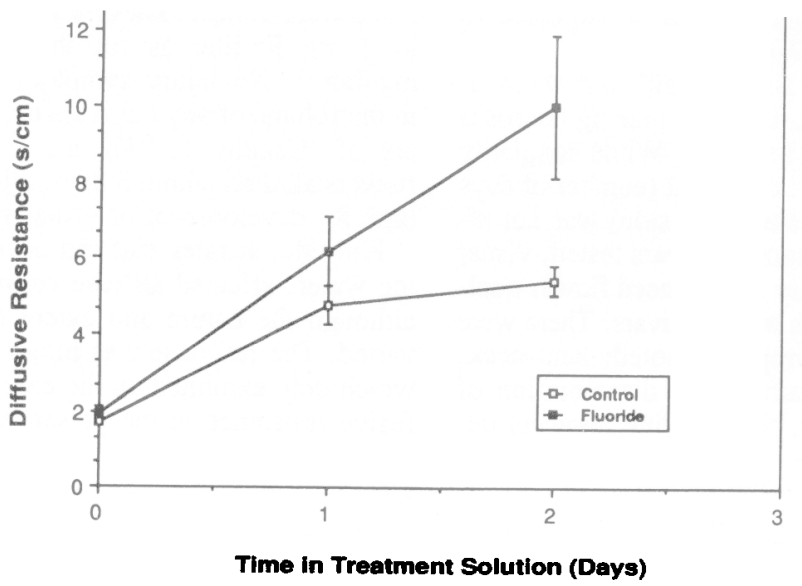

Fig. 1. Effect of a keeping solution containing 0 or $4 \mathrm{mg} \mathrm{F}$-/liter on leaf diffusive resistance of cut 'Prive' roses. Overall means for these treatments are significantly different at $P=0.05$. 
Table 1. Effect of fluoride in the keeping solution on maximum fresh weight gain, flower opening, and longevity of various cut rose cultivars.

\begin{tabular}{|c|c|c|c|c|c|c|c|c|c|c|c|c|}
\hline \multirow{3}{*}{ Cultivar } & \multicolumn{3}{|c|}{$\begin{array}{c}\text { Flowers } \\
\text { per treatment } \\
\text { (no.) } \\
\end{array}$} & \multicolumn{3}{|c|}{$\begin{array}{l}\text { Maximum fresh } \\
\text { wt gain }(\mathrm{g})\end{array}$} & \multicolumn{3}{|c|}{$\begin{array}{c}\text { Opcning } \\
\text { (mean rating) }\end{array}$} & \multicolumn{3}{|c|}{$\begin{array}{l}\text { Longevity } \\
\text { (days) }\end{array}$} \\
\hline & \multicolumn{12}{|c|}{$\mathrm{F}^{-}$in keeping solution (mg.liter-1) } \\
\hline & $\overline{0}$ & 2 & 4 & 0 & 2 & 4 & 0 & 2 & 4 & 0 & 2 & 4 \\
\hline$\overline{\text { Bridal Pink }}$ & 10 & 0 & 10 & 1.0 & 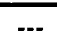 & $-0.6^{* * *}$ & 4.5 & $\ldots$ & $3.4^{* * *}$ & $\overline{4.3}$ & $\begin{array}{ll}\ldots \\
-\cdots\end{array}$ & $2.1^{* * *}$ \\
\hline Bridal White & 3 & 4 & 4 & 2.8 & 3.0 & $2.5^{\mathrm{NS}}$ & 4.1 & 3.8 & $3.9^{\mathrm{NS}}$ & 5.7 & 5.5 & $5.0^{\mathrm{NS}}$ \\
\hline Candia & 3 & 4 & 4 & 3.0 & 2.0 & $2.1^{y}$ & 4.7 & 5.3 & $4.7^{\mathrm{NS}}$ & 3.0 & 3.0 & $3.0^{\mathrm{NS}}$ \\
\hline Golden Wave & 3 & 4 & 4 & 6.8 & 6.6 & $6.9^{\mathrm{NS}}$ & 5.2 & 5.4 & $5.3^{\mathrm{NS}}$ & 4.7 & 4.3 & $4.3^{\mathrm{NS}}$ \\
\hline Kyria & 10 & 0 & 10 & 1.8 &.-- & $2.0^{\mathrm{NS}}$ & 4.0 & -- & $4.0^{\mathrm{NS}}$ & 5.7 & --. & $5.1^{\mathrm{NS}}$ \\
\hline $\begin{array}{l}\text { Prive } \\
\text { Pro }\end{array}$ & 10 & 0 & 10 & 3.1 & ... & $2.4^{* *}$ & 4.8 & ... & $4.4^{* * *}$ & 5.9 & -.- & $5.7^{\mathrm{Ns}}$ \\
\hline Samantha (Trial 1 ) & 10 & 0 & 10 & 1.9 & -- & $0.7^{* * * *}$ & 3.3 & -.. & $3.0^{* * *}$ & 6.5 & --- & $3.9^{* * *}$ \\
\hline Samantha (Trial 2) & 3 & 3 & 3 & 4.8 & 2.9 & $2.6^{x}$ & 4.5 & 4.4 & $4.8^{\mathrm{NS}}$ & 13.0 & 7.0 & $6.7^{w}$ \\
\hline Sonia & 10 & 0 & 10 & 2.7 & $\ldots$ & $2.1^{\mathrm{NS}}$ & 4.1 & -.. & $4.3^{* *}$ & 5.5 & $\ldots$ & $4.9^{\mathrm{NS}}$ \\
\hline
\end{tabular}

zOpening on a scale from 1 (a bud opened slightly at the apex) through 7 (an open flower with visible stamens).

y Linear and quadratic trends significant at $P=0.05$ and 0.1 , respectively.

xLinear and quadratic trends significant at $P=0.001$ and 0.05 , respectively.

"Linear and quadratic trends significant at $P=0.001$.

NS. $" \cdots$ Cultivar in fluoride does not differ significantly from control or differs at $P=0.01$ or 0.001 , respectively.

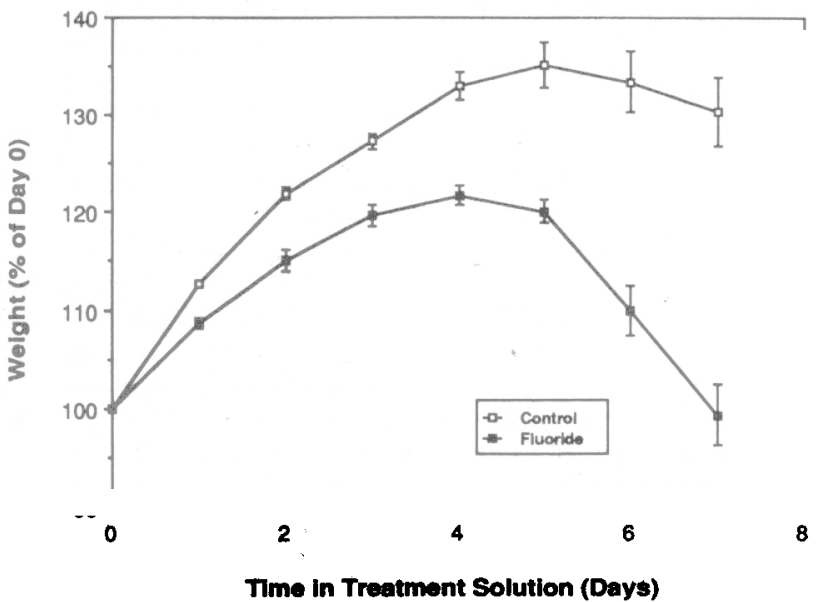

Fig. 2. Effect of a keeping solution containing 0 or $4 \mathrm{mg}$ F-/liter on fresh weight (expressed as a oercent of weight on Day 0) of cut 'Samantha' roses. Overall means for these treatments are significantly different at $P=0.05$.

In most cultivars, opening was delayed or prevented with F- (e.g., in flowers that developed bent-neck), while in 'Sonia' opening was advanced. Failure to open and develop normally has also been noted in 'Tropicana' roses in water containing F- (Waters, 1968). Failure to absorb water normally and enzymatic changes associated with F- exposure (Miller et al., 1983) would be expected to influence flower opening.

Longevity of 'Bridal Pink' and 'Samantha' roses was shortened by placing the roses in F- solutions (Table 1). While longevity as defined in this experiment (number of days to bent-neck or petal abscission) was not affected by F- for most cultivars tested, visual symptoms of injury and reduced flower quality were evident in most cultivars. There were three types of symptoms noted: bent-neck, marginal petal damage, or discoloration of the entire flower. 'Bridal Pink' flowers de- veloped bent-neck on Day 2. 'Bridal White' 'Golden Wave', 'Samantha', and 'Sonia' developed marginal petal discoloration or necrosis and, in some flowers, this inhibited normal petal expansion and resulted in a distorted flower. Change in color of the entire petal from pink to purple was noted in 'Prive'. Injury symptoms were usually evident on Day 3 and were almost as severe for flowers held in $2 \mathrm{mg} \mathrm{F}$-/liter as for those held in 4 $\mathrm{mg} \cdot$ liter $^{-1}$. No injury symptoms were seen in the foliage of any cultivars or in the flowers of 'Candia' or 'Kyria', but 'Candia' flowers all died within 3 days, allowing little time for development of visual symptoms.

Fluoride, at rates that can occur in drinking water, affected all rose cultivars tested, although the nature and extent of response varied. The response was minor in 'Kyria', which only exhibited an increase in leaf diffusive resistance in the presence of F. In- jurv was extensive in 'Samantha' and 'Bridal Pink', which exhibited increases in leaf diffusive resistance, reductions in fresh weight gain, changes in the degree of flower opening, and reductions in longevity in solutions with F-. Wholesalers and retailers need to be aware of the symptoms of injury and may need to use water without F-, such as deionized or distilled water. In areas where high levels of F- are known to be present, those cultivars less susceptible to visual injury symptoms could be selected for sale.

\section{Literature Cited}

Leone, I. A., E.G. Brennan, R.H. Dairies, and W.R. Robbins. 1948. Some effects of fluorine on peach, tomato, and buckwheat when absorbed through the roots. Soil Sci. 66:259-266.

Lohr, V.I. and C.H. Pearson-Mims. 1989. Fluoride in keeping solutions injures cut red roses. HortScience 24(2):389.

Miller, G. W., M. Yu, and J.C. Pushnik. 1983. Basic metabolic and physiologic effects of fluorides on vegetation, p. 83-104. In: J.L. Shupe, H.B. Peterson, and N.C. Leone (eds.). Fluorides: Effects on vegetation, animals, and humans. Intl. Symp. on Fluorides, Utah State Univ., Salt Lake City.

Poovaiah, B.W. and H.H. Wiebe. 1973. Influence of hydrogen fluoride fumigation on the water economy of soybean plants. Plant Physiol. 51:396-399.

Spierings, F. 1969. Injury to cut flowers of gladiolus by fluoridated water. Netherlands J. Plant Pathol. 75:281-286.

Tjia, B., F.J. Marousky, and R.H. Stamps. 1987. Response of cut gerbera flowers to fluoridated water and a floral preservative. HortScience 22:896-897.

U.S. Government. 1986. National primary and secondary drinking water regulations; Fluoride. Fed. Reg. 51(63):11396-11412.

Waters, W.E. 1968. Influence of well water salinity and fluorides on keeping quality of "Tropicana" roses. Proc. Fla. State Hort. Soc. 81:355-359. 